\title{
ANALISIS PENGARUH KINERJA PERUSAHAAN, KEBIJAKAN HUTANG, UKURAN PERUSAHAAN, DAN NILAI PERUSAHAAN TERHADAP TINGKAT PENGEMBALIAN INVESTASI PADA PERUSAHAAN PROPERTY DAN REAL ESTATE YANG TERDAFTAR DI BEI PERIODE 2014-2016
}

\author{
Julianti Levina Kosman \\ Program Studi Magister Manajemen Universitas Tarumanagara \\ julianti.kosman@gmail.com \\ Indra Widjaja \\ Program Studi Magister Manajemen Universitas Tarumanagara
}

\begin{abstract}
The purpose of this research is to examine empirically the influence of company performance, debt policy, firm size and firm value toward retun on investment. In this research, researcher used four independent variables and one dependent variabel. Company performance is proxied by Return On Equity (ROE), Debt policy is proxied by Debt to Equity Ratio (DER), firm size is proxied by Natural Logarithm of Total Asset (SIZE), firm value is proxied by Price Book Value (PBV), and return on investment is proxied by Stock Return (RETURN). The sample of the research consist of 36 property and real estate companies listed in Indonesia Stock Exchange in the period 2014-2016. This research used quantitative analysis with panel data estimation methods with time series and cross section data used 5\% significance level. The result shows that company performance have a positive effect and insignificant toward stock return, debt policy have a negative effect and significant toward stock return, firm size has a negative effect and insignificant toward stock return and firm value have a positive effect and significant toward the stock return.
\end{abstract}

Key ords: Company Performance (ROE), Debt Policy (DER), Firm Size (SIZE), Firm Value (PBV), Stock Return (RETURN)

\section{PENDAHULUAN}

Suatu perusahaan dalam rangka mengembangkan usahanya membutuhkan tambahan modal yang tidak sedikit. Tambahan modal dapat diperoleh melalui hutang ataupun dengan menambah jumlah kepemilikan saham baru. Pasar modal menjadi salah satu sarana bagi perusahaan untuk memenuhi kebutuhan dana dengan menjual hak kepemilikan perusahaan kepada masyarakat. Ekspektasi dari para investor terhadap investasinya adalah memperoleh return (tingkat pengembalian) sebesar-besarnya dengan risiko tertentu. Terdapat dua komponen utama yang menjadi sumber dari return saham yaitu capital gain dan dividen. Dalam pengambilan keputusan investasi, investor harus melakukan penilaian harga saham terlebih dahulu yang didasarkan dari informasi yang disajikan oleh perusahaan yang menggambarkan kondisi perusahaan saat ini dan prospek perusahaan di masa mendatang.

Perusahaan dengan kinerja perusahaan yang baik dapat terlihat dari profitabilitas yang tinggi. Semakin tinggi kemampuan perusahaan memperoleh laba, maka semakin besar return yang diharapkan investor (Saidi, 2004) dan semakin banyak pula investor yang akan menanamkan saham pada perusahaan tersebut. Informasi lainnya yang dipertimbangkan oleh investor juga termasuk kebijakan hutang perusahaan. Kebijakan hutang suatu perusahaan dapat mencerminkan kemampuan perusahaan dalam memenuhi kewajibannya dan seberapa besar ekuitas dari para pemegang saham yang digunakan untuk membiayai hutang. Semakin besar total hutang perusahaan dibandingkan dengan total ekuitasnya, maka risiko gagal bayar yang dihadapi oleh perusahaan akan semakin besar. Ukuran perusahaan juga dianggap mampu 
dalam menarik investor. Semakin besar ukuran dan skala perusahaan, maka akan semakin mudah perusahaan dalam memperoleh sumber pendanaan baik yang bersifat internal maupun eksternal. Nilai Perusahaan menjadi salah satu tolak ukur bagi para investor terhadap perusahaan. Nilai perusahaan adalah nilai jual suatu perusahaan dalam pasar modal yang kemudian dikaitkan dengan harga saham. Apabila harga saham meningkat, kemakmuran pemegang saham juga akan meningkat.

Berdasarkan uraian diatas, maka yang menjadi rumusan masalah dalam penelitian ini adalah: (1)Apakah kinerja perusahaan memiliki pengaruh terhadap tingkat pengembalian investasi?, (2) Apakah kebijakan hutang memiliki pengaruh terhadap tingkat pengembalian investasi?, (3)Apakah ukuran perusahaan memiliki pengaruh terhadap tingkat pengembalian investasi?, (4) Apakah nilai perusahaan memiliki pengaruh terhadap tingkat pengembalian investasi?

\section{TELAAH KEPUSTAKAAN}

Tingkat Pengembalian Investasi (Stock Return). Return adalah tingkat pengembalian yang diperoleh atas waktu serta risiko terhadap investasi yang telah dilakukan. Salah satu faktor yang membuat para investor menanamkan modalnya saat berinvestasi adalah return yang tinggi, dengan return yang tinggi maka investor berharap akan mendapatkan imbalan yang tinggi atas investasi yang dilakukan (Eduardus, 2010). Menurut Ang (1997), komponen suatu return (pengembalian) terdiri dari dua jenis, yaitu : Current Income yaitu keuntungan yang diperoleh melalui pembayaran yang bersifat pembayaran periodic dan Capital gain yaitu keuntungan yang diterima karena adanya selisih antara harga jual dan harga beli suatu instrument investasi.

Kinerja Perusahaan. Mardyati, Ahmad dan Putri (2012) menyatakan bahwa rasio profitabilitas mengukur kemampuan perusahaan dalam menghasilkan keuntungan dari kegiatan bisnis yang dilakukakan. Profitabilitas yang tinggi merupakan suatu keberhasilan perusahaan yang dalam memperoleh laba berdasarkan aktivanya maupun berdasarkan modal sendiri. Menjaga tingkat profitabilitas merupakan hal yang penting bagi sebuah perusahaan karena profitabilitas yang tinggi merupakan keinginan setiap perusahaan.

Kebijakan Hutang. Dalam rangka untuk pembiyaan aktivitas perusahaan, kebijakan hutang mempengaruhi perusahaan karena hutang merupakan beban yang bersifat tetap. Kegagalan perusahaan dalam membayar bunga atas hutang dapat menyebabkan kesulitan keuangan dan kemungkinan menyebabkan perusahaan berakhir dengan kebangkrutan. Di sisi lain, kebijakan hutang perusahaan yang tepat dapat memberikan subsidi pajak atas bunga yang dapat menguntungkan pemegang saham. Oleh sebab itu, kebijakan hutang harus dilakukan secara tepat agar dapat menyeimbangkan antara keuntungan dan kerugian yang dapat timbul.

Ukuran Perusahaan. Salah satu tolak ukur yang menunjukkan besar kecilnya perusahaan adalah ukuran aktiva perusahaan. Perusahaan yang memiliki total aktiva besar menunjukkan bahwa perusahaan tersebut telah mencapai tahap kedewasaan dimana dalam tahap ini arus kas perusahaan sudah positif dan dianggap memiliki prospek yang baik dalam jangka waktu relatif lama, selain itu juga mencerminkan bahwa perusahaan relatif lebih stabil dan mampu menghasilkan laba dibandingkan perusahaan dengan total aktiva yang kecil (Daniati dan Suhairi, 2006)

Nilai Perusahaan. Tujuan sangat penting bagi keberhasilan perusahaan, oleh sebab itu pendirian suatu perusahaan harus memiliki tujuan yang jelas. Tujuan perusahaan adalah untuk memaksimalkan nilai perusahaan. Nilai perusahaan sendiri merupakan harga yang bersedia dibayar oleh calon pembeli atau investor apabila perusahaan tersebut dijual. Nilai perusahaan adalah sangatlah penting karena dengan nilai perusahaan yang tinggi akan diikuti 
oleh tingginya kemakmuran pemegang saham. Semakin tinggi nilai perusahaan semakin tinggi nilai harga saham.

\section{HIPOTESIS PENELITIAN}

Berdasarkan kajian teoritis, kajian empiris dan dasar logika, maka hipotesis alternatif yang diajukan dalam penelitian ini adalah sebagai berikut.

- Pengaruh Kinerja Perusahaan terhadap Tingkat Pengembalian Investasi

Kinerja perusahaan yang dalam hal ini yang dilihat dari profitabilitas perusahaan adalah kemampuan perusahaan untuk menghasilkan laba dari kegiatan operasionalnya. Oleh karena itu, semakin tinggi keuntungan yang diperoleh makan semakin tinggi pula return yang diperoleh investor.

Ha1: Kinerja perusahaan memiliki pengaruh positif terhadap tingkat pengembalian investasi.

- Pengaruh Kebijakan Hutang terhadap Tingkat Pengembalian Investasi

Kebijakan hutang adalah kebijakan yang menentukan seberapa besar kebutuhan dana perusahaan dibiayai oleh hutang. Berdasarkan teori sinyal (Signalling Theory), perusahaan yang meningkatkan hutang bisa dipandang sebagai perusahaan yang yakin dengan prospek perusahaan di masa depan sehingga investor akan menangkap sinyal tersebut yang menyatakan bahwa perusahaan memiliki prospek yang baik di masa depan.

Ha2: Kebijakan Hutang memiliki pengaruh positif terhadap tingkat pengembalian investasi.

- Pengaruh Ukuran Perusahaan terhadap Tingkat Pengembalian Investasi

Aktiva merupakan tolak ukur besaran atau skala suatu perusahaan. Biasanya perusahaan besar mempunyai aktiva yang besar pula nilainya. Secara teoritis perusahaan yang lebih besar memiliki kepastian (certainty) yang lebih besar daripada perusahaan kecil sehingga akan mengurangi tingkat ketidakpastian mengenai prospek perusahaan ke depan.

Ha3: Ukuran perusahaan memiliki pengaruh positif terhadap tingkat pengembalian investasi

\section{- Pengaruh Nilai Perusahaan terhadap Tingkat Pengembalian Investasi}

Price Book Value (PBV) suatu perusahaan menggambarkan nilai pasar keuangan terhadap manajemen dan organisasi dari perusahaan yang sedang berjalan (going concern). Semakin tinggi PBV, maka semakin tinggi pula penilaian investor terhadap perusahaan, maka harga saham akan meningkat di pasaran sehingga akan berdampak pada peningkatan return saham perusahaan yang bersangkutan..

Ha4: Nilai perusahaan memiliki pengaruh positif terhadap tingkat pengembalian investasi.

\section{METODOLOGI PENELITIAN}

Penelitan ini menggunakan data sekunder yang diperoleh dari laporan keuangan tahunan perusahaan yang tutup buku pada tanggal 31 Desember selama tahun 2014-2016. Teknik pengambilan sampel yang digunakan adalah purposive sampling. Beberapa kriteria yang digunakan peneliti dalam pemilihan sampel adalah : (1) Perusahaan tersebut terdaftar di BEI berturut-turut tahun 2014-2016, (2) Perusahaan tersebut mempublikasikan laporan keuangan secara lengkap dari tahun 2014-2016 dengan tahun buku yang berakhir pada 31 
Desember, (3) Jenis perusahaan adalah perusahaan go public yang tergolong dalam industri property dan real estate yang terdaftar di BEI. Berdasarkan kriteria penarikan sampel yang telah disebutkan, terdapat 36 perusahaan yang memenuhi kriteria dalam penarikan sampel dan diperoleh data sebanyak 108 data. Teknik analisis data yang digunakan adalah data panel yakni gabungan antara time- series dan cross-section yang diamati secara simultan dari waktu ke waktu. Adapun pengolahan data akan dilakukan dengan menggunakan program EVIEWS (Econometric Views) 9.0. Teknik pengolahan data yang digunakan dalam penelitian ini adalah analisis statistik deskriptif, teknik data panel dengan model pendekatan fixed effect, dan uji regresi linear berganda.

\section{DEFINISI OPERASIONAL}

Ringkasan variabel dan definisi operasional variabel dari penelitian ini dapat dilihat pada tabel 1 berikut ini:

\section{TABEL 1}

\begin{tabular}{|c|c|c|c|c|}
\hline No. & Variabe1 & $\begin{array}{c}\text { Sub } \\
\text { Variabe1 }\end{array}$ & Indikator & $\begin{array}{c}\text { Skala } \\
\text { Pengukułan }\end{array}$ \\
\hline 1 & $\begin{array}{l}\text { DEPENDEN } \\
\text { Stock Return }\end{array}$ & $\begin{array}{c}\text { Closing } \\
\text { stock price } \\
\text { at time t } \\
\text { and closing } \\
\text { stock price } \\
\text { at time t-1 } \\
\text { (prior } \\
\text { period t) }\end{array}$ & $\frac{P t-P t-1}{P t-1}$ & Rasio \\
\hline 1 & $\begin{array}{c}\text { INDEPENDEN } \\
\text { Return On } \\
\text { Equity Ratio }\end{array}$ & $\begin{array}{c}\text { Net } \\
\text { Income, } \\
\text { Equity }\end{array}$ & $\frac{\text { Net Income }}{\text { Equity }}$ & Rasio \\
\hline 2 & $\begin{array}{c}\text { Debt to Equity } \\
\text { Ratio }\end{array}$ & $\begin{array}{c}\text { Total Debt, } \\
\text { Total } \\
\text { Equity }\end{array}$ & $\frac{\text { Total Debt }}{\text { Total Equity }}$ & Rasio \\
\hline 3 & Firm Size & Sales & $\begin{array}{c}\text { Natural Logarithm of Total } \\
\text { Assets }\end{array}$ & Rasio \\
\hline 4 & $\begin{array}{c}\text { Price Book } \\
\text { Value }\end{array}$ & $\begin{array}{l}\text { Price per } \\
\text { Share, } B V \\
\text { of Equity } \\
\text { per Share }\end{array}$ & $\frac{\text { Price per share }}{B V \text { of Equity per Share }}$ & Rasio \\
\hline
\end{tabular}

\section{HASIL PENELITIAN}

\section{Analisis Deskriptif}

Pada variabel dependen yaitu tingkat pengembalian investasi (return), rata-rata yang diperoleh adalah sebesar 0,070851 dengan standar deviasi sebesar 0,387137. Adapun nilai minimum dan maksimum dari variabel ini adalah -0,669565 dan 1,133333. Berdasarkan data statistik deskriptif, variable independen yaitu kinerja perusahaan yang diproksikan menggunakan return on equity (ROE) menunjukkan rata-rata sebesar 10,31578 dengan nilai minimum sebesar $-15,22000$ dan nilai maksimum sebesar 41,16000. Standar deviasi dari ROE adalah 9,724877. Semakin tinggi nilai ROE, berarti kinerja perusahaan dalam pencapaian laba akan semakin baik. Debt to equity ratio (DER) menunjukkan nilai rata-rata sebesar 0,728148 dengan nilai minimum 0,030000 dan memiliki nilai maksimum 2,020000. Standar deviasi yang dimiliki oleh DER adalah sebesar 0,487906. Semakin rendah DER, maka risiko gagal bayar yang kemungkinan akan dapat dihadapi oleh perusahaan akan semakin kecil. Nilai rata-rata Price book value (PBV) sebesar 1,681944 dengan nilai minimum sebesar 0,100000 dan nilai maksimum 8,300000. Standar deviasi dari price book value adalah 1,617979. Semakin tingginya PBV dipandang, suatu perusahaan akan memiliki prospek yang semakin baik. Firm Size (SIZE) memiliki rata-rata sebesar 28,99676 dengan nilai minimum sebesar 25,16170 dan nilai maksimum sebesar 31,45101 Standar deviasi yang dimiliki variabel firm size adalah 1,473373 . 


\section{Model Panel Data-Uji Chow dan Haussman}

Uji pemilihan model dilakukan dengan melakukan uji Chow dan uji Hausman. Pengujian pada kedua persamaan yaitu memperoleh hasil Probabilitas dari Cross-section $F$ yaitu sebesar $0,0000<0,05$. Sehingga dapat disimpulkan bahwa model terbaik untuk persamaan adalah Fixed Effect Model (FEM). Pada pengujian berikutnya yaitu uji Hausman, pada persamaan memperoleh probabilitas dari cross-section random sebesar $0,0000<0,05$ sehingga model yang terpilih adalah Fixed Effect Model (FEM).

\section{Uji Hipotesis (uji - F, uji t, dan uji determinasi ganda $\left(\mathbf{R}^{2}\right)$ )}

Hasil output dari pendekatan model fixed effect adalah :

TABEL 2

Dependent Variable: RETURN

Method: Panel Least Squares

Date: 05/20/18 Time: 21:18

Sample: 20142016

Periods included: 3

Cross-sections included: 36

Total panel (balanced) observations: 108

\begin{tabular}{|c|c|c|c|c|}
\hline Variable & Coefficient & Std. Error & $\mathrm{t}$-Statistic & Prob. \\
\hline $\mathrm{C}$ & 5.321464 & 5.747880 & 0.925813 & 0.3578 \\
\hline $\mathrm{ROE}$ & 0.004647 & 0.006134 & 0.757539 & 0.4513 \\
\hline DER & -0.838199 & 0.369503 & -2.268452 & 0.0265 \\
\hline SIZE & -0.184595 & 0.195734 & -0.943089 & 0.3490 \\
\hline PBV & 0.395042 & 0.073133 & 5.401670 & 0.0000 \\
\hline \multicolumn{5}{|c|}{ Effects Specification } \\
\hline \multicolumn{5}{|c|}{ Cross-section fixed (dummy variables) } \\
\hline R-squared & 0.538623 & \multirow{7}{*}{\multicolumn{2}{|c|}{$\begin{array}{l}\text { Mean dependent var } \\
\text { S.D. dependent var } \\
\text { Akaike info criterion } \\
\text { Schwarz criterion } \\
\text { Hannan-Quinn criter. } \\
\text { Durbin-Watson stat }\end{array}$}} & 0.070851 \\
\hline Adjusted R-squared & 0.274009 & & & 0.387137 \\
\hline S.E. of regression & 0.329860 & & & 0.897822 \\
\hline Sum squared resid & 7.398932 & & & 1.891204 \\
\hline Log likelihood & -8.482401 & & & 1.300603 \\
\hline F-statistic & 2.035507 & & & 2.492845 \\
\hline Prob(F-statistic) & 0.005062 & & & \\
\hline
\end{tabular}

Sumber : Hasil pengolahan data dari Eviews 9.0

Persamaan regresi yang diperoleh dari hasil pengujian pada tabel 2 adalah:

Tingkat pengembalian investasi $=5,321464+0.004647$ Kinerja Perusahaan $(\mathrm{ROE})-$ 0.838199 Kebijakan Hutang (DER) - 0.184595 Ukuran Perusahaan (SIZE) + 0,395042 Nilai Perusahaan $(\mathrm{PBV})+\mathrm{e}$

Uji F Berdasarkan hasil uji pada tabel 2, dapat diketahui bahwa nilai prob (F statistics) adalah sebesar 0,005062 ( prob < 0,05). Hal ini berarti paling sedikit terdapat satu variabel independen (kinerja perusahaan, kebijakan hutang, ukuran perusahaan dan nilai perusahaan) yang mempengaruhi variabel dependen (tingkat pengembalian investasi) dengan tingkat keyakinan $95 \%$. 


\section{Uji t}

Pengaruh kinerja perusahaan terhadap tingkat pengembalian investasi

Hasil pengujian menyimpulkan adanya pengaruh yang tidak signifikan atas kinerja perusahaan yang diproksikan dengan return on equity ratio (ROE) terhadap tingkat pengembalian investasi (RETURN) dimana nilai prob $=0,4513$ ( prob >0,05). Hasil penelitian ini mengindikasikan bahwa kinerja perusahaan yang dilihat dari profitabilitasnya tidak menjadi pertimbangan yang penting bagi investor. Hal ini bisa disebabkan karena peningkatan ROE akan dianggap dikarenanakan peningkatan laba atau karena penurunan modal. Apabila perusahaan mampu mengelola modal secara baik, dan perusahaan mendapatkan laba, maka dengan laba yang tinggi, return juga akan meningkat.

Pengaruh kebijakan hutang terhadap tingkat pengembalian investasi

Hasil pengujian menyimpulkan bahwa kebijakan hutang berpengaruh signifikan terhadap tingkat pengembalian investasi dimana nilai prob $=0,0265$ ( prob $<0,05)$. Kebijakan hutang yang memiliki nilai koefisien regresi negatif sebesar $-0,838199$ menunjukkan kebijakan hutang berlawanan arah terhadap tingkat pengembalian investasi. Hal ini disebabkan karena semakin tinggi nilai DER suatu perusahaan akan memberikan sinyal bahwa tingkat permodalan perusahaan yang dibayai pihak luar semakin besar, sehingga akan menyebabkan tingkat pengembalian investasi berkurang karena laba yang diperoleh perusahaan cenderung akan digunakan untuk membayar utang dibandingkan untuk dividen

Pengaruh ukuran perusahaan terhadap nilai perusahaan

Hasil pengujian menyimpulkan bahwa ukuran perusahaan berpengaruh tidak signifikan terhadap tingkat pengembalian investasi dimana nilai prob $=0,3490$ ( prob $>0,05$ ). Ukuran perusahaan yang menunjukkan tanda koefisien regresi negatif, yaitu sebesar $-0,184595$ terhadap tingkat pengembalian investasi karena peningkatan ukuran perusahaan yang dipandang dari peningkatan aktivanya akan diikuti dengan peningkatan beban tetap yang menyebabkan keuntungan perusahaan juga berkurang sehingga return investor kemungkinan juga menurun.

Pengaruh nilai perusahaan terhadap tingkat pengembalian investasi

Hasil pengujian menyimpulkan bahwa nilai perusahaan berpengaruh signifikan terhadap tingkat pengembalian investasi dimana nilai prob $=0,0000$ ( prob $<0,05$ ). Nilai perusahaan yang menunjukkan tanda koefisien regesi positif, yaitu 0,395042 disebabkan karena nilai perusahaan yang baik dianggap investor menandakan kinerja perusahaan yang baik sehingga dapat mempengaruhi peningkatan harga saham dan berarti memperoleh capital gain.

Uji determinasi ganda $\left(\mathbf{R}^{2}\right)$ Dari hasil pengujian dapat dilihat bahwa Adjusted R-Squared adalah sebesar 0,274009 atau 27,40\%. Artinya adalah variansi dari tingkat pengembalian investasi (Y) dapat dijelaskan oleh variansi ROE (X1), DER ( X2), SIZE ( X3), dan PBV (X4), sedangkan sisanya $72,60 \%$ dapat dijelaskan oleh variabel lainnya yang tidak dijelaskan dalam penelitian.

\section{KESIMPULAN}

Berdasarkan hasil penelitian yang telah dilakukan, dapat disimpulkan beberapa hal berikut (1) Kinerja perusahaan (ROE) berpengaruh positif tidak signifikan terhadap tingkat pengembalian investasi (RETURN), (2) Kebijakan hutang (DER) berpengaruh negatif signifikan terhadap tingkat pengembalian investasi (RETURN), (3) Ukuran perusahaan (SIZE) berpengaruh negatif tidak signifikan terhadap tingkat pengembalian investasi 
(RETURN), (4) Nilai perusahaan (PBV) berpengaruh positif signifikan terhadap tingkat pengembalian investasi (RETURN)

\section{DAFTAR PUSTAKA}

Ajija, Shochrul R., dkk. 2011.Cara Cerdas Menguasai EViews. Jakarta : Salemba Empat.

Ang, Robert. 1997. Buku Pintar Pasar Modal Indonesia (The Intelligent Guide to Indonesian Capital Market). Jakarta : Media Soft Indonesia.

Fidhayatin, Septy Kurnia dan Nurul Hasanah Uswati Dewi. 2012. "Analisis Nilai Perusahaan, Kinerja Perusahaan, dan Kesempatan Bertumbuh Perusahaan terhadap Return Saham pada Perusahaan Manufaktur yang Listing di BEI". The Indonesian Accounting Review Volume 2 No.2, 203-214.

Hendriksen, Eldon S dan Nugroho W. 1997.Teori Akuntansi. $4^{\text {th }}$ edition, Jilid 1, terjemahan Hermawan Wibowo, Jakarta : Erlangga.

Hartono, Jogiyanto. 2010. Teori Portofolio dan Analisis Investasi. Yogyakarta : BPFE

Mardiyati, Ahmad dan Putri. 2012. "Pengaruh Kebijakan Dividen, Kebijakan Hutang dan Profitabilitas Terhadap Nilai Perusahaan Manufaktur yang terdaftar di Bursa Efek Indonesia (BEI) periode 2005-2010. Jurnal Riset Manajemen Sains Indonesia (JRMSI) Vol.3 No.1 2012

Mariani, Ni Luh Lina, Fridayana Yudiaatmaja dan Ni Nyoman Yulianthini. 2016.'Pengaruh Profitabilitas dan Leverage terhadap Return Saham". E-Journal Bisma Universitas Pendidikan Ganesha Jurusan Manajemen Volume 4.

Pande, I Komang Arta Wibawa dan Luh Komang Sudjarni. 2012. "Pengaruh Kinerja Keuangan terhadap Return Saham Perusahaan Sektor Food and Beverages di BEI". EJurnal Fakultas Ekonomi dan Bisnis Universitas Udayana : 799-815

Prihadi, Toto. 2012. Praktis Memahami Laporan Keuangan Sesuai IFRS \& PSAK. Cetakan ke-2. Jakarta : PPM Manajemen.

Sekaran, U., \& Bougie, R. (2013). Research Methods for Business: A skill building approach, sixth edition. United Kingdom: Wiley.

Tandelilin, Eduardus. 2010. Portofolio dan Investasi Edisi Pertama, Yogyakarta : Universitas Gajah Mada. 


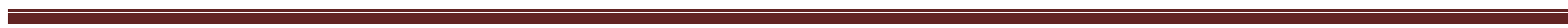
$\cdot$ 